Vol 12, Issue 2, 2019

\title{
SCREENING OF PHYTOCHEMICALS AND IN VITRO ANTIOXIDANT ANALYSIS OF IXORA MACROTHYRSA (TEJISM. AND BINN.)
}

\author{
SURUTHI SARASWATHI G, VICTOR AROKIA DOSS D* \\ Department of Biochemistry, PSG College of Arts and Science, Coimbatore, Tamil Nadu, India. Email: ragasuru@gmail.com
}

Received: 26 June 2018, Revised and Accepted: 02 October 2018

ABSTRACT

Objective: The aim of the study was to investigate the phytochemical screening and quantitative and in vitro antioxidant analysis of the hydroethanolic leaf extract of Ixora macrothyrsa (Tejism. and Binn.)

Methods: The powdered plant material was extracted using different solvents for phytochemical screening. For the quantitative analysis, proteins, carbohydrates, tannins, free amino acids, and proline were estimated. In vitro antioxidants such as ascorbic acid, total phenols, chlorophyll, and carotenoids were also analyzed using standard methods.

Results: The preliminary qualitative analysis of the hydroethanolic leaf extract of $I$. macrothyrsa showed the presence of carbohydrates, proteins, alkaloids, flavonoids, phenols, saponins, glycosides, and tannins. The secondary metabolites such as proteins, carbohydrates, tannin, free amino acid, and proline were quantified as $24.57 \pm 0.61 \mathrm{mg} / \mathrm{g}, 11.07 \pm 0.09 \mathrm{mg} / \mathrm{g}, 6.17 \pm 0.20 \mathrm{mg} / \mathrm{g}, 9.20 \pm 0.17 \mathrm{mg} / \mathrm{g}$, and $34.47 \pm 0.44 \mathrm{mg} / \mathrm{g}$, respectively. In vitro antioxidants such as ascorbic acid, total phenols, chlorophyll, and carotenoid were estimated to be $35.73 \pm 0.28 \mathrm{mg} / \mathrm{g}, 15.9 \pm 0$. $\mathrm{mg} / \mathrm{g}$, $9.33 \pm 0.09 \mathrm{mg} / \mathrm{g}$, and $5.9 \pm 0.58 \mathrm{mg} / \mathrm{g}$, respectively.

Conclusion: It can be concluded that the hydroethanolic extract of the leaves of $I$. macrothyrsa showed the presence of major secondary metabolites and has potent antioxidant activity.

Keywords: Ixora macrothyrsa, Hydroethanolic leaf extract, Phytochemicals, In vitro antioxidant, Secondary metabolites.

(C) 2019 The Authors. Published by Innovare Academic Sciences Pvt Ltd. This is an open access article under the CC BY license (http://creativecommons. org/licenses/by/4. 0/) DOI: http://dx.doi.org/10.22159/ajpcr.2019.v12i2.28106

\section{INTRODUCTION}

Phytochemicals are biologically active compounds present in plants which contribute for its color, aroma, and flavor. Phytochemicals protect the plant from various factors such as stress, pollution, ultraviolet (UV) exposure, and insects [1]. Phytochemicals assemble in various parts of the plants, and the pigment molecule gets accumulated in the outer layer of plant tissues [2]. These secondary metabolites defend humans against various diseases by stimulating the immune system [3]. The phytochemical constituents include alkaloids, flavonoids, tannins, phenolics, saponins, and several essential oils [4]. The bioactive substances from the plant are excellent sources of medicine that play a major role in human health against a large number of diseases [5].

Antioxidants protect humans against infectious diseases by scavenging the free radicals [6]. Antioxidants scavenge the free radicals by inhibiting the oxidation process [7]. Medicinal plants constitute a large variety of free radical scavenging molecules including phenols, flavonoids, vitamins, and terpenoids which are potent antioxidants [8]. Natural antioxidants from plant constituents are more effective in the prevention of oxidative stress [9]. Among the naturally occurring antioxidants, ascorbic acid, carotenoid, and phenolic compounds are much more effective than others [10]. Natural antioxidants are risk free and they are protective against viruses, cancer, and tumor [11].

Ixora is a genus of shrubs and short trees which comprises about 400 taxa. It belongs to the family Rubiaceae and subfamily Ixoroideae [12]. Ixora are grown in Indian garden which comprises of colored, beautiful flowers, and leaves [13]. The roots and flowers of the plant are involved in the treatment of dysentery, loss of appetite, nausea, and chronic ulcers [14]. Furthermore, the leaf of Ixora macrothyrsa has a potent antidiabetic property by lowering the blood glucose level [15].
Plant collection and authentication

I. macrothyrsa (Tejism. and Binn.) was collected from Coimbatore, Tamil Nadu. The plant was identified and authenticated by the Taxonomist, Botanical Survey of India (BSI), Coimbatore, Tamil Nadu, India, and the authentication number for the plant is BSI/ SRC/5/23/2013-14/Tech/1417.

\section{METHODS}

Plant extraction and qualitative phytochemical analysis The leaves of I. macrothyrsa were shade dried and grounded to a coarse powder by a mechanical device. The extract was prepared using different solvents, namely water, $50 \%$ ethanol, ethanol, acetone, benzene, petroleum ether, and chloroform, by cold maceration process. The filtrate was then used for the preliminary phytochemical analysis. The phytochemical analysis was carried out for the presence of phytoconstituents using standard procedures [16].

\section{Preparation of hydroethanolic extract}

The leaves of I. macrothyrsa were soaked in 50\% alcohol and macerated in cold for 3 days. Occasional stirring was done during maceration. The suspension was then filtered using a fine muslin cloth, and the residue was removed. The filtrate was taken in a round-bottomed glass flask, and the sample was evaporated to dryness at a low temperature in a rotary evaporator. Finally, dark brown-colored crystals obtained were then stored in an airtight desiccator. The crystals are then used to carry out quantitative analysis and in vitro antioxidant study.

\section{Quantitative analysis of phytochemicals}

Determination of protein

Weighed $100 \mathrm{mg}$ of crude plant extract and homogenized with $5.0 \mathrm{ml}$ of ice-cold phosphate buffer. The sample was centrifuged at $2000 \mathrm{rpm}$ for $5 \mathrm{~min}$. Supernatant was separated and added equal volume of 
$10 \%$ ice-cold trichloroacetic acid to precipitate protein. The tube was incubated for $10 \mathrm{~min}$ at $4^{\circ} \mathrm{C}$ for $1 \mathrm{~h}$. The precipitated protein was centrifuged and the supernatant was discarded. The pellet was then dissolved in $1.0 \mathrm{ml}$ of $0.1 \mathrm{~N} \mathrm{NaOH} .0 .5 \mathrm{ml}$ of the protein solution was taken and mixed with $5.0 \mathrm{ml}$ of alkaline copper reagent. The tube was shaken well and allowed to stand at room temperature for $10 \mathrm{~min}$. Protein standard was taken in different aliquots and added $5.0 \mathrm{ml}$ of alkaline copper reagent. A separate tube with distilled water and $5.0 \mathrm{ml}$ of alkaline copper reagent served as a blank. Then, added 0.5 $\mathrm{ml}$ of Folin-Ciocalteu reagent to all the tubes and the final volume was made up to a known quantity using distilled water. The tubes were then incubated for $30 \mathrm{~min}$ in the dark, and the optical density of the solution was read at $660 \mathrm{~nm}$ [17].

\section{Determination of carbohydrate}

$100 \mathrm{mg}$ of plant sample was taken in a boiling tube. The sample was then hydrolyzed by adding $5.0 \mathrm{ml}$ of $2.5 \mathrm{~N} \mathrm{HCl}$ in boiling water bath and cooled to room temperature. The reaction mixture was neutralized by adding sodium carbonate and made up to $100 \mathrm{ml}$ with distilled water and centrifuged. Supernatant was collected and $1.0 \mathrm{ml}$ of sample was taken for analysis. Standards were prepared and $0.2-1.0 \mathrm{ml}$ of the working standard was taken. $1.0 \mathrm{ml}$ of water serves as a blank. To all the tubes, the volume was made up to $1.0 \mathrm{ml}$ with distilled water. $4.0 \mathrm{ml}$ of anthrone reagent was added. Tubes were heated for $8 \mathrm{~min}$ in a boiling water bath. Cooled rapidly and green color obtained was read spectrophotometrically at $630 \mathrm{~nm}$ [18].

\section{Determination of tannin}

About $500 \mathrm{mg}$ of crude plant crystals was taken in a $250 \mathrm{ml}$ conical flask containing $75 \mathrm{ml}$ of distilled water. The flask was boiled in a boiling water bath for $30 \mathrm{~min}$ and transferred to separate tube. The tube was centrifuged at $2000 \mathrm{rpm}$ for $20 \mathrm{~min}$. The supernatant was collected in $100 \mathrm{ml}$ volumetric flask and made up to a known volume. $1.0 \mathrm{ml}$ of the plant extract was transferred to a $100 \mathrm{ml}$ volumetric flask containing $75 \mathrm{ml}$ of distilled water. To this, $5.0 \mathrm{ml}$ of Folin-Denis reagent and $10 \mathrm{ml}$ of sodium carbonate solution are added and made up to $100 \mathrm{ml}$ with distilled water. The flask was shaken well and incubated for $30 \mathrm{~min}$, and the absorbance was read at $700 \mathrm{~nm}$ against a reagent blank (water) [19].

\section{Determination of proline}

About $100 \mathrm{mg}$ of crude plant sample was taken and homogenized with $0.5 \mathrm{ml}$ of $3 \%$ aqueous sulfosalicylic acid. The tube was then centrifuged at $12,000 \mathrm{~g}$ for $10 \mathrm{~min}$. To $1.0 \mathrm{ml}$ of the homogenized tissue, added $1.0 \mathrm{ml}$ acid-ninhydrin and $1.0 \mathrm{ml}$ of glacial acetic acid and incubated for $1 \mathrm{~h}$ at $100^{\circ} \mathrm{C}$, and the reaction was terminated in an ice bath. The reaction mixture was extracted by the addition of $2.0 \mathrm{ml}$ of toluene. The contents were mixed vigorously and incubated at room temperature for $30 \mathrm{~min}$. The chromophore containing toluene was warmed and its optical density was measured at $520 \mathrm{~nm}$ using toluene as a blank. The proline concentration was determined from a standard curve using D-proline [20].

\section{Determination of total free amino acid}

Nearly $100 \mathrm{mg}$ of dried plant crystals was taken in a tube. The sample was homogenized with $5.0 \mathrm{ml}$ of $80 \%$ ethanol and centrifuged at $2000 \mathrm{rpm}$ for $10 \mathrm{~min}$. The supernatant was discarded, and the pellet was reextracted with the same solvent and centrifuged again. The supernatant were pooled. To the supernatant, an equal volume of petroleum ether was added to remove the chlorophyll pigments using separation funnel. The lower layer was taken as sample. Added $0.5 \mathrm{ml}$ of acetate buffer to the $1.0 \mathrm{ml}$ of alcoholic extract, followed by the addition of $1.0 \mathrm{ml}$ of $1 \%$ ninhydrin solution. The reaction mixture was heated in a boiling water bath at $100^{\circ} \mathrm{C}$ for $15 \mathrm{~min}$. The color developed on the tube was then cooled. The volume was made up to $10 \mathrm{ml}$ with distilled water. $0.5 \mathrm{ml}$ distilled water with all the reagents was served as a blank. The color intensity was measured at $570 \mathrm{~nm}$ [21].

\section{In vitro antioxidant analysis}

\section{Determination of ascorbic acid}

\section{Extraction}

About $3 \mathrm{~g}$ of air-dried powdered sample was ground with $25 \mathrm{ml}$ of $4 \%$ oxalic acid, and the extract was filtered. $10 \mathrm{ml}$ of the filtrate was taken in a conical flask. To remove the ethanolic hydrogen atoms, bromine water was added drop by drop with constant stirring until the filtrate turned orange-yellow. The excess of bromine was removed by blowing in the air. Using $4 \%$ oxalic acid solution, the final volume was made up to $25 \mathrm{ml}$ and it was used as the source material.

\section{Estimation}

$2.0 \mathrm{ml}$ aliquots of the above extract were pipetted into each of the different test tubes and the volume was made up to $3 \mathrm{ml}$ with distilled water. $1.0 \mathrm{ml}$ of $2 \%$ 2, 4-dinitrophenylhydrazine reagent was added followed by 1 or 2 drops of $10 \%$ thiourea to each test tube. The contents were mixed and kept at $37^{\circ} \mathrm{C}$ for $3 \mathrm{~h}$. Added $7.0 \mathrm{ml}$ of $80 \%$ sulfuric acid to dissolve the orange-red osazone crystals, and the absorbance was measured at $540 \mathrm{~nm}$ in UV-visible spectrophotometer against a reagent blank. The ascorbic acid content present in the sample was calculated using ascorbic acid as standard with the help of standard graph [22]

\section{Determination of total phenol}

$1.0 \mathrm{mg}$ of plant extract was taken in a dry test tube. Added $0.5 \mathrm{ml}$ of Folin-Ciocalteu reagent and allowed to stand for 15 min followed by the addition of $1.0 \mathrm{ml}$ of $10 \%$ sodium carbonate solution. Finally, the mixtures were made up to $10 \mathrm{ml}$ with distilled water and allowed to stand for $30 \mathrm{~min}$ at room temperature. Total phenols present in the plant extract were determined spectrophotometrically at $760 \mathrm{~nm}$. The reaction mixture without sample was used as blank. Total phenol content of leaf extract was determined using gallic acid as a standard with the help of standard graph [23].

\section{Determination of chlorophyll}

$0.5 \mathrm{~g}$ of sample was taken in a clean mortar and was macerated with the addition of $5.0-15 \mathrm{ml}$ of $80 \%$ acetone. The contents were centrifuged at $5000 \mathrm{rpm}$ for 5-8 $\mathrm{min}$. The supernatant was taken in a $100 \mathrm{ml}$ volumetric flask. The residue was again ground with $5.0-15 \mathrm{ml}$ of $80 \%$ acetone and again centrifuged. The supernatant was then transferred to the same volumetric flask. The procedure was repeated until the residue became colorless. The mortar and the pestle were washed thoroughly with $80 \%$ acetone, and the supernatant was taken to the same volumetric flask. Finally, the volume was made up to $100 \mathrm{ml}$ by adding $80 \%$ acetone. The absorbance of the solution was measured spectrophotometrically at 645 $\mathrm{nm}$ and $663 \mathrm{~nm}$ against reagent blank (80\% acetone) [24].

\section{Calculation}

The amount of chlorophyll of the extract as mg chlorophyll gram tissue will be:

Total Chlorophyll $(\mathrm{mg} / \mathrm{g})=20.2\left(\mathrm{~A}_{645}\right)+8.02\left(\mathrm{~A}_{663}\right) \times \frac{\mathrm{V}}{1000 \times \mathrm{W}}$

Where

$A=$ Absorbance of specific wavelengths

$\mathrm{W}=$ Fresh weight of the tissue extracted.

\section{Determination of carotenoids}

About $1 \mathrm{~g}$ of sample was taken and extracted with $100 \mathrm{ml}$ of $80 \%$ methanol solution. The reaction mixture was centrifuged at $4000 \mathrm{rpm}$ for $30 \mathrm{~min}$. The supernatant was concentrated to dryness. The residue was then dissolved in $15 \mathrm{ml}$ of diethyl ether. Added $15 \mathrm{ml}$ of $10 \%$ methanolic Potassium hydroxide solution, and the contents were washed with $5 \%$ ice-cold saline water to remove alkali. The free ether extract was dried over anhydrous sodium sulfate for $2 \mathrm{~h}$. The ether extracts were filtered, and its absorbance was measured at $450 \mathrm{~nm}$ using ether as blank [25]. 


\section{RESULTS AND DISCUSSION}

\section{Phytochemical analysis}

The preliminary phytochemical analysis of the hydroethanolic leaf extract of I. macrothyrsa revealed the presence of carbohydrates, proteins, alkaloids, flavonoids, phenols, steroids, saponins, tannins, and glycosides as shown in Table 1.

The extraction of various phytochemicals was more efficaciously done in polar solvents such as acetone, ethanol, and water than the non-polar solvents. Furthermore, the hydroethanolic leaf extract of I. macrothyrsa under the study showed the presence of a maximum number of the tested phytochemicals. Hence, it can be reported that the hydroethanolic leaf extract of I. macrothyrsa was the best one for extracting the active principle when compared to other solvents.

\section{Quantitative phytochemical analysis}

The quantitative analysis of the hydroethanolic leaf extract of I. macrothyrsa was found to contain $24.57 \pm 0.61 \mathrm{mg} / \mathrm{g}$ of protein (Fig. 1). Protein is the most important primary compound with regard to the human body. Since they act as building blocks, it involves in repairing the tissues in our body. Hence, for building body or muscles, a high protein diet is recommended. The body makes use of proteins for energy production, when it lacks the presence of carbohydrates and fats [26].

The quantitative analysis of the hydroethanolic leaf extract of I. macrothyrsa was found to contain $11.07 \pm 0.09 \mathrm{mg} / \mathrm{g}$ of carbohydrate (Fig. 1). Carbohydrates are important for controlling immunological recognition, in defense against pathogens, protein folding and placement. Since carbohydrate in plants is considered as a third bioinformative macromolecule, it is used in determining the quality of food, fruits, and its production [27].

The quantitative analysis of the hydroethanolic leaf extract of I. macrothyrsa was found to contain $6.17 \pm 0.20 \mathrm{mg} / \mathrm{g}$ of tannin
(Fig. 1). Tannin helps in the inhibition of fungi, yeasts, bacteria, and viruses. Tannins are rich in antioxidants and help in free radical scavenging activity, antimicrobial, gastroprotective, and antiulcerogenic activities. Moreover, tannin helps in the inhibition of lipid peroxidation in heart mitochondria and tends to possess anti-fibrotic effects [28]. Tannin helps to improve the digestive utilization of feed due to a reduced degradation of protein in the rumen and a subsequent increase in amino acid flow to the small intestine [29].

The quantitative analysis of the hydroethanolic leaf extract of I. macrothyrsa was found to contain $9.20 \pm 0.17 \mathrm{mg} / \mathrm{g}$ of proline (Fig. 1). Proline acts as an osmolyte and antioxidant and helps the plants to maintain the survival of cell turgor [30]. Proline is a proteinogenic amino acid with an exceptional conformational rigidity and it is important for primary metabolism [31]. Proline has been reported to enhance growth, physiological, biochemical, and anatomical characteristics and helps to improve antioxidant defense system in plants during salinity stress [32].

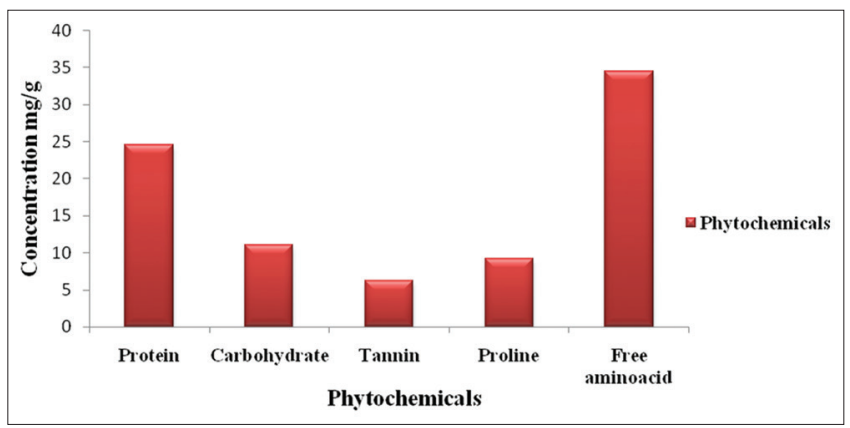

Fig. 1: Quantitative phytochemical analysis

Table 1: Qualitative estimation of phytochemicals

\begin{tabular}{|c|c|c|c|c|c|c|c|}
\hline Test & Water & $50 \%$ ethanol & Ethanol & Acetone & Benzene & Petroleum ether & Chloroform \\
\hline \multicolumn{8}{|l|}{ Carbohydrates } \\
\hline Fehling's test & + & + & + & + & - & - & + \\
\hline Benedict's test & + & + & + & - & - & - & - \\
\hline Molisch's test & - & - & - & - & + & + & + \\
\hline \multicolumn{8}{|l|}{ Proteins } \\
\hline Millon's test & + & - & + & - & - & -- & - \\
\hline Biuret test & + & + & - & - & + & + & - \\
\hline Ninhydrin test & - & + & - & + & - & - & _- \\
\hline \multicolumn{8}{|l|}{ Steroids } \\
\hline Salkowski's test & - & + & - & - & - & - & + \\
\hline Thiols & - & - & - & - & + & - & + \\
\hline \multicolumn{8}{|l|}{ Alkaloids } \\
\hline Dragendorff's test & - & - & - & - & - & - & - \\
\hline Wagner's test & - & + & + & - & - & - & - \\
\hline Mayer's test & - & - & - & - & - & - & - \\
\hline \multicolumn{8}{|l|}{ Flavonoids } \\
\hline Alkaline reagent test & - & - & - & - & - & - & - \\
\hline Zinc hydrochloride test & + & + & + & + & _- & _- & - \\
\hline Shinoda test & + & + & + & - & + & + & - \\
\hline \multicolumn{8}{|l|}{ Phenols } \\
\hline Ferric chloride test & + & + & + & + & + & - & - \\
\hline Lead acetate test & + & + & + & + & - & - & - \\
\hline \multicolumn{8}{|l|}{ Saponins } \\
\hline Foam test & - & + & + & - & - & - & - \\
\hline \multicolumn{8}{|l|}{ Glycosides } \\
\hline Legal's test & - & - & - & - & + & + & + \\
\hline Keller-Kiliani test & + & + & - & - & - & - & - \\
\hline \multicolumn{8}{|l|}{ Tannins } \\
\hline Ferric chloride test & + & - & + & - & + & + & + \\
\hline Lead acetate test & + & + & - & - & + & - & + \\
\hline
\end{tabular}

+indicates the presence of the compound and-indicates the absence of the compound 
The quantitative analysis of the hydroethanolic leaf extract of I. macrothyrsa was found to contain $34.47 \pm 0.44 \mathrm{mg} / \mathrm{g}$ of free amino acid (Fig. 1). Amino acid plays a major role in protein synthesis and in the formation of secondary metabolites that participate in cell signaling, gene expression, regulation of homeostasis, phosphorylation of proteins, synthesis of hormones, and antioxidant activity. Furthermore, amino acids involve in various physiological processes, namely formation of skeletal muscle, atrophic conditions, sarcopenia, and cancer [33].

\section{In vitro antioxidant analysis}

Quite a high percentage of ascorbic acid has been detected in the leaves of the plant (35.73 $\pm 0.28 \mathrm{mg} / \mathrm{g}$ ) (Fig. 2). Ascorbic acid is a potent antioxidant involving in the flowering time of the plant, senescence, apoptosis, and responses to pathogens against diseases [34]. Due to its antioxidant activity, it impairs the production of free radicals involving the formation of intracellular substances including collagen, bone matrix, and tooth dentine [35]. Therefore, a clinical manifestation of scurvy hemorrhage from mucous membrane of the mouth and gastrointestinal tract, anemia, and pains in the joints can be related to the association of ascorbic acid and normal connective tissue metabolism [36].

The amount of phenol content in the hydroethanolic leaf extract of I. macrothyrsa was found to be $15.9 \pm 0.17 \mathrm{mg} / \mathrm{g}$ (Fig. 2). Phenols are important plant constituents because it has the ability to scavenge hydroxyl groups and may contribute directly to antioxidative action [37]. Phenols increases bile secretion, reduces blood cholesterol, and antimicrobial activity against some strains of bacteria such as Staphylococcus aureus. In addition to this, phenols have antiulcer, anti-inflammatory, cytotoxic, antitumor, antispasmodic, and antidepressant properties [38].

The hydroethanolic leaf extract of I. macrothyrsa was found to contain $9.33 \pm 0.09 \mathrm{mg} / \mathrm{g}$ (Fig. 2) of chlorophyll and $5.9 \pm 0.58 \mathrm{mg} / \mathrm{g}$ (Fig. 2) of carotene. Chlorophyll belongs to the class of primary compounds that capture sunlight and makes it available to plant system for its cultivation on photosynthesis [39]. Chlorophyll acts as an oxygenator. Deposition of metals and drugs is eliminated from the body by the purifying action of chlorophyll. Chlorophyll also helps in the prevention of constipation and attenuates the discomfort caused by gastritis [40]. Carotenoids act as photoprotective agent and may reduce the risk of sunburns, photoallergy, and even some types of skin cancer. It was proved that carotenoids have a positive role on the epithelialization process and influence the cell cycle progression of the fibroblasts [41].

\section{CONCLUSION}

The results obtained from the present study indicate that the leaves of I. macrothyrsa have a higher amount of phytochemicals and strong antioxidant activity. Therefore, the leaves may have the capability to scavenge the free radicals and reduce the risk caused by the free radicals. However, further studies are required to prove the free radical scavenging activity and isolation of other phytoconstituents in the plants.

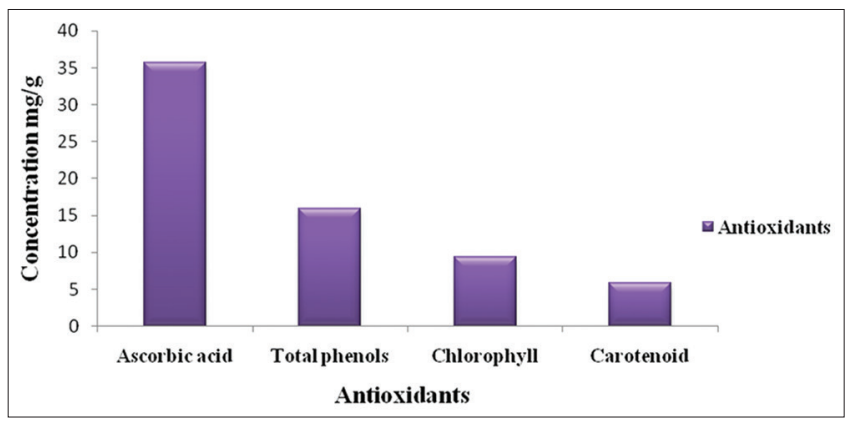

Fig. 2: Quantification of antioxidants

\section{AUTHORS' CONTRIBUTIONS}

The authors have contributed equally to this work.

\section{CONFLICTS OF INTEREST}

The authors declare that there are no conflicts of interest regarding the publication of this article.

\section{REFERENCES}

1. Hasler CM, Blumberg JB. Symposium on phytochemicals: Biochemistry and physiology. J Nutr 1999;129:756-7.

2. Gibson EL, Wardle J, Watts CJ. Fruit and vegetable consumption, nutritional knowledge and beliefs in mothers and children. Appetite 1998:31:205-28.

3. Rao BN. Bioactive phytochemicals in Indian foods and their potential in health promotion and disease prevention. Asia Pac J Clin Nutr 2003;12:9-22.

4. Edoega HO, Okwu DE, Mbaebie BO. Phytochemical constituents of some Nigerian medicinal plants. Afr J Biotechnol 2005;4:685-9.

5. Ates A, Erdogrul OT. Antimicrobial activities of various medicinal and commercial plant extracts. Turk J Biol 2003;27:157-62.

6. Mohanasundari L, Suja S. Antioxidant and free radical scavenging activity of the mixture of ethanolic extracts of Alpina speciosa and Alpina calcarata rhizome. Int J Pharm Sci 2016;2016:164-70.

7. Mattson MP, Cheng A. Neurohormetic phytochemicals: Low-dose toxins that induce adaptive neuronal stress responses. Trends Neurosci 2006;29:632-9.

8. Cai YZ, Sun M. Antioxidant activity of betalins from plants of the Amaranthacea. J Agric Food Chem 2003;51:2288-94.

9. Umesh TG, Dilkalal A. Evaluation of antioxidant potential and reducing power of callus induced from leaves of Asystasia gangetica (L.) T. Anderson. Int J Pharm Sci 2014;6:532-8.

10. Duh PD, Tu YY, Yen GC. Antioxidants activity of aqueous extract of Harnjyur (Chrysanthemum morifolium). Lebensm Wiss Technol 1999;32:269-77.

11. Arnous A, Markis DP, Kefalas P. Effect of principal polyphenolic components in relation to antioxidant characteristics of aged red wines. J Agric Food Chem 2001;49:5736-42.

12. Fosberg FR, Sachet HH. Three cultivated ixoras (Rubiaceae). Baileya 1989;23:74-85.

13. Husain T, Paul SR. Giant stomata in some members of the genus Ixora L. (Rubiaceae). Curr Sci 1985;54:524.

14. Maniyar Y, Bhixavatimath P. Evaluation of hypoglycemic and hypolipidaemic activities of the aqueous extract of the leaves of Ixora coccinea Linn in diabetic Rats. J Clin Diagn Res 2011;5:1381-4.

15. Saraswathi GS, Doss VA. Antidiabetic activity of hydroethanolic leaf extract of Ixora macrothysa (Tejism. and Binn) on streptozotocin induced diabetic rats. Int J Sci Res 2014;3:23-4.

16. Santhi S, Sengottuvel R. Qualitative and quantitative phytochemical analysis of Moringa concanensis (nimmo). Int J Curr Microbiol Appl Sci 2016:5:633-40

17. Lowry OH, Rosebrough NJ, Farr AL, Randall RJ. Protein measurement with the folin phenol reagent. J Biol Chem 1951;193:265-75.

18. Mahadevan A, Sridhar R. Methods in Physiological Plant Pathology. Chennai: Sivakami Publications; 1982. p. 121-2.

19. Sadasivam S, Manickam A. Enzymes. In: Biochemical Methods for Agricultural Sciences. Chennai: Wiley Eastern Ltd Publications; 1992. p. $119-22$.

20. Bates IS, Waldren RP, Teare JD. Rapid determination of free proline for water stress studies. Plant Soil 1973;39:205-7.

21. Moore S, Stein WH. Photometric ninhydrin methods for use in the chromatography of amino acids. J Biol Chem 1948;176:367-88.

22. Cakmak I, Marschner H. Magnesium deficiency and high light intensity enhance activities of Superoxide dismutase, ascorbate peroxidase and glutathione reductase in bean leaves. Plant Physiol 1992;98:1222-7.

23. Portes MT, Damineli DS, Ribero RV, Monteiro JA, Souza GM. Evidence of Higher photosynthetic plasticity in the early successional Guazuma ulmifolia L. Compared to the late successional Hymenae courbaril L. Grown in contrasting light environments. Braz J Biol 2010;70:75-83.

24. Weissman MM, Bland RC, Canino GJ, Faravelli C, Greenwald S, Hwu HG, et al. Cross-national epidemiology of major depression and bipolar disorder. JAMA 1996;276:293-9.

25. Jensen A. Chlorophyll and carotenoids. In: Hallebust JA, Craigie JS, editors. Handbook of Physiochemical and Biochemical Methods. UK: Cambridge University Press; 1978. p. 5-70. 
26. Nehete JY, Bhambar RS, Narkhede MR, Gawali SR. Natural proteins: Sources, isolation, characterization and applications. Pharm Rev 2013;7:107-16.

27. Qureshi MD, Stecher G, Bonn GK. Standardization of phytopharmaceuticals: Qualitative evaluation and quantification of carbohydrates in medicinal plants using TLC, matrix free MELDITOF-MS and GC-MS. J Chem Soc Pak 2014;36:338-42.

28. Anbukkarasi M, Dhamotharan R, Janarthanam B. Studies on phytochemical screening, tannin content and antibacterial activity from leaf and callus extracts of Memecylon umbellatum. Asian J Pharm Clin Res 2017;10:265-9.

29. Butter N.L, Dawson JM, Wakelin D, Buttery PJ. Effect of dietary tannin and protein concentration on nematode infection (Trichostrongylus colubriformis) in lambs. J Agri Sci 2000;134:89-99.

30. Huang J, Hirji R, Adam L, Rozwadowski KL, Hammerlindl JK, Keller WA, et al. Genetic engineering of glycinebetaine production toward enhancing stress tolerance in plants: Metabolic limitations. Plant Physiol 2000;122:747-56.

31. Abdelhamid MT, Rady MM, Osman, A, Shabdalla MA. Exogenous application of proline alleviates salt-induced oxidative stress in Phaseolus vulgaris L. Plants. J Horti Sci Biotechnol 2013;88:439-46.

32. Dawood MG, Taie HA, Nassar RM, Abdelhamid MT, Schmidhalter U. The changes induced in the physiological, biochemical and anatomical characteristics of Vicia faba by the exogenous application of proline under seawater stress. S Afri J Bot 2014;93:54-63.
33. Moran-Palacio EF, Tortoledo-Ortiz O, Yanez-Farias GA, ZamoraAlvarez LA, Stephens-Camacho NA, Sonanez-Organis JG, et al. Determination of amino acids in medicinal plants from Southern Sonora, Mexico. Trop J Pharm Res 2014;13:601-6.

34. Nicholas A. The function and metabolism of ascorbic acid in plants. Ann Bot 1996;34:661-9.

35. Aqil F, Ahmed I, Mehmood Z. Antioxidant and free radical scavenging properties of twelve traditionally used Indian medicinal plants. Turk J Biol 2006;30:177-83.

36. Malencić D, Gasic O, Popović M, Boza P. Screening for antioxidant properties of Salvia reflexa hornem. Phytother Res 2000;14:546-8.

37. Sawant O, Kadam J, Ghosh R. In vitro free radical scavenging and antioxidant activity of Adiantum lunulactum. J Herb Med Toxicol 2009;3:39-44.

38. Ghasemzadeh A, Jaafar HZ, Rahmat A. Antioxidant activities, total phenolics and flavonoids content in two varieties of Malaysia young ginger (Zingiber officinale roscoe). Molecules 2010;15:4324-33.

39. Murray AP, Gibbss CF, Longmore AR. Determination of chlorophyll in marine waters: Inter comparison of a rapid HPLC method with full HPLC, spectrophotometric and fluorometric methods. Mar Chem 1986;19:211-27.

40. Gopi S, Varma K, George R. A short review on the medicinal properties of chlorophyll juice. Asian Pharm Tech 2014;2:89-94.

41. Lee J, Jiang S, Levine N, Watson RR. Carotenoid supplementation reduces erythema in human skin after simulated solar radiation exposure. Proc Soc Exp Biol Med 2000;223:170-4. 